\title{
Implications and reflections on the 2010 Supreme Court ruling on Canada's AHR Act
}

This article was published in the following Dove Press journal:

International Journal of Women's Health

28 November 2011

Number of times this article has been viewed

\section{Raywat Deonandan \\ Tarun Rahman}

Interdisciplinary School of Health Sciences, University of Ottawa

Ottawa, Ontario, Canada
Correspondence: Raywat Deonandan, Interdisciplinary School of Health Sciences, University of Ottawa, 43 Templeton St, Ottawa, Ontario, Canada KIN 6XI

Tel + I 6135625800 ext 8377

Fax+l 866 68I 3897

Email ray@deonandan.com
Abstract: In December, 2010, Canada's 6 year old Assisted Human Reproduction Act was successfully challenged in the Supreme Court of Canada. There may be important implications for public health and the evolution of reproductive technologies in this country.

Keywords: public health, reproductive medicine, IVF, ART, in vitro fertilization (IVF)

In 2004, the Parliament of Canada passed this nation's Assisted Human Reproduction (AHR) Act, ${ }^{1}$ a piece of federal legislation that resulted, in part, from the lengthy Royal Commission on New Reproductive Technologies (RCNRT), ${ }^{2}$ which was struck to contextualize the new set of technologies within the milieu of Canadian values and concerns.

The AHR Act identified which specific practices were to be controlled and prohibited in Canada and required the creation of a governmental agency, Assisted Human Reproduction Canada (AHRC), to monitor AHR practices and oversee enforcement of the Act and its regulations. In addition, Health Canada created the Assisted Human Reproduction Implementation Office (AHRIO), to develop relevant regulations and associated policy. In accordance with the RCNRT's recommendation, AHRC also began to explore the creation of a national AHR surveillance system.

After a challenge from Quebec to the AHR Act's constitutionality, the Supreme Court of Canada ruled ${ }^{3}$ in December of 2010 that many aspects of the AHR Act were unconstitutional. As summarized by Baylis, ${ }^{4}$ the legal issue before the Court was whether the "pith and substance" of the contested sections of the AHR Act were:

1. to protect morality, safety, and public health; and

2. to regulate and promote the benefits of medical practice and research related to assisted human reproduction.

According to the Constitution Act of $1867,,^{5}$ the first component above is a federal matter, while the second is a provincial matter. In general, the Supreme Court decided that Ottawa was within its right to pass legislation regarding criminality, for instance in the banning of human cloning; but that the right to regulate clinics and clinicians remains the purview of the provinces. This paper presents some reflections on the possible implications of the ruling on public health, the philosophy of health care and health policy in Canada, and on the disposition of our AHR industry.

AHR is relevant to the discussion of the evolution of health care in Canada for at least two reasons. First, given its inclusion of philosophies pertaining to life, death, sex, family and reproduction, how a society chooses to conceptualize its relationship 
with, and attitudes toward, AHR ultimately reflects its core values. And second, in Canada, AHR is one of those rare medical realms, along with such things as laser eye surgery, dental care and various laboratory services, which includes a privatized stratum. Thus, it is a vanguard for the probable expansion of medical privatization within Canada's socialized system.

With the initial passing of the Act, Canada joined a small group of nations which have enacted federal legislation relating to AHR. The USA has failed to establish a national regulatory framework, and given the likelihood of crossborder care between Canada and the USA, it is interesting to consider the extent to which the Americans' decentralized regulatory system influenced the evolution of the Canadian case. Merchant ${ }^{6}$ believes that the key difference between the USA and nations with federal AHR regulations (such as Canada and many European nations) is that the latter tend to formally consider health to be a human right, contrary to the individualistic American approach. According to some, the development of Canada's AHR legal and ethical framework has indeed been influenced by our proximity to the USA. ${ }^{7}$ Does the diminishing of Canada's federal framework, then, indicate a retreat from an ethic of considering health within a rights-based philosophy? More defensibly, such a retreat may signal a larger trend toward the decentralization of measures to adjudicate the marriage of medicine with commerce.

The creation of Canada's AHR policy was the result of disparate, often conflicting forces. In addition to Canada's proximity to the USA, Jones and Salter ${ }^{7}$ identified "feministinformed activism", the power and influence of professional clinical bodies, and of course Canada's famous federalprovincial jurisdictional challenges as being key vectors in forming the AHR Act. The constitutional challenge to the Act was, of course, the result of our federal-provincial power struggles. But enactment of the elements that remain after the Supreme Court ruling may still be subject to the influences of the other forces described by Jones and Salter. ${ }^{7}$ In other words, the Act was born from conflict, its challenge was yet another stage of that conflict, and it is likely that conflict will continue to surround and define it until another concerted national effort is made to consolidate and elucidate Canadians' attitudes toward assisted reproduction.

Clearly, the formation of legislation and policy around AHR is complicated by inputs from a vast array of seemingly unrelated viewpoints and perspectives, many of which ultimately speak to core societal values. (And while these viewpoints have some commonalities globally, the key influencers are most definitely culture-specific: the forces forging AHR policy in Europe and the USA, for instance, will not necessarily be the same forces at play in Canada.) Any changes to sweeping federal legislation will necessarily impact the same wide array of stakeholders in this country to varying degrees, and not just the immediate clinical players.

In this paper, we suggest that the likely impacts of the Supreme Court's revisiting of the AHR Act that are most relevant to public health are the potential creation of a domestic reproduction tourism industry and the probable slowing of the creation of a national ART surveillance system.

Among the values-based foci of the Act was the criminalization of payment for gametes, embryos, reproductive material, and surrogacy. This scenario was likely a contributor to the global reproductive tourism industry, wherein Western clients would travel to less developed countries, such as India, to offer money for such services as ovum purchasing or surrogacy on demand. In India alone, the reproductive tourism industry is now worth between $\$ 500$ million $^{8}$ and $\$ 2.3$ billion $^{9}$ annually.

Controlled and prohibited activities that the Supreme Court did not find unconstitutional will remain homogenously enforced across the country. But certain controlled activities have been struck from the legislation, and individual provinces can now choose whether to legislate in these areas. As a result of the Supreme Court decision, aspects of the disposition of human reproductive tissue are no longer a federal matter, but a provincial one. Provinces and territories can choose to regulate activities, such as the storing or transportation of in vitro embryos, but may choose not to. This presents the possibility of a heterogeneous domestic landscape of regulation, with respect to certain practices.

Baylis identified the number of embryos transferred per IVF cycle as an area in which there will likely be diversity across provinces, ${ }^{4}$ correctly identifying heterogeneity in this matter as both an ethical and health concern. In absence of legislation on this matter, or at the very least stringently followed professional guidelines, there may be a tendency for economic considerations to fill the legislative void. A client may argue strongly for a multiple embryo transfer, for instance, to minimize the number of cycles she expects to fund before a successful live birth, while adopting the increased medical risk that such a choice embodies. This is the scenario that gave rise to California's "Octo-Mom," Nadya Suleman, who chose to dangerously carry eight embryos to term, due in large part to her inability to pay for many more cycles. ${ }^{10}$ It is that sort of situation that Baylis alluded to when characterizing the regulatory scenario prior to the AHR Act as one born of a "Wild West culture."4 
If intra-Canadian heterogeneity in legislation on these key practices does indeed become the norm, the prospect then arises of a domestic reproductive tourism industry, with service seekers traveling a gradient from more restrictive provinces to less restrictive ones. The likelihood of such a domestic market arising in a meaningful fashion is balanced against the realities of global economics. Well-established reproductive tourism services in developing countries like India are able to offer high quality services for dramatically lower prices than can be offered in wealthier nations. The gradient that drives the international industry is largely considered to be an economic one, which would likely trump a domestic gradient, which would also likely be based more upon regulatory rigour without offering significant cost advantages, due to Canada's federal ban on payment for gametes and surrogacy, which has not been affected by the Supreme Court's decision.

The anticipated smallness of such a domestic fertility tourism market, relative to the international one, might change if less restrictive provinces were to experience organized investments in infrastructure relevant to the ease of provision of reproductive services to visitors, much like the state-level investments made in India to help grow that country's medical tourism industry. It will be interesting to see how the Canadian ART industry re-organizes itself in coming months to potentially exploit such a domestic market, perhaps initially in the form of ART clinics pursuing greater connections with extra-provincial physicians who might refer clientele.

From a population health perspective, of most immediate concern is the disposition of the RCNRT's recommendation to establish a national surveillance system for AHR. With the probable diminishing of the scope of AHRC's mandate, the agency's leadership in creating a true federal surveillance system may also diminish. Such a system is required for three main reasons. First, due to anonymous gamete donation from a shrinking pool of donors, there is a non-trivial likelihood of half siblings living in close proximity to one another. In 2007, the media reported on a donor who may have fathered as many as 50 children in his region. ${ }^{11}$ His is not a unique story in the lay media. The threat of unconscious consanguine coupling is therefore real. Surveillance is a viable strategy for mitigating (though certainly not eliminating) the risk of such couplings, depending upon the extent of collection of personal donor information.

Second, assisted reproductive technologies can be considered a vector for disease. ${ }^{12}$ Both infectious and inherited diseases can be transmitted through the gamete donation process. ${ }^{12}$ Surveillance is the least expensive and most efficient method for detecting disease clusters that may be caused by AHR, and potentially for tracing their sources, again depending upon the extent of collection of personal information.

Third, despite being in common usage for over three decades, AHR is still a set of very new technologies. Many long term and multigenerational health outcomes have yet to be assessed in a systematic fashion. ${ }^{13}$ Surveillance presents the opportunity to detect and study previously unidentified outcomes that may affect public health, refinement of the technologies, and the perspectives of policymakers.

The inability of Canada's federal agencies' to mandate participation in a national AHR surveillance system is concerning because the political and resource barriers faced by individual provinces to create such a system are significant. A viable approach might be for Ottawa to lead the coordination and provide funding for a multi-provincial system.

The history of AHR suggests that the technologies' evolution will steer society in new directions. Our legal, ethical, philosophical and clinical perspectives will shift in response. The recent change to Canada's federal regulatory framework is but one manifestation of this shift. The coming months will reveal the first signs of the new face of AHR in this country. And while those participating in the reproductive services phenomenon still constitute a relatively small proportion of Canadians seeking medical services, the manner in which a society chooses to conceptualize and regulate its reproductive technology services will ultimately reflect a population's core values and philosophies, thus making this issue a socially and politically preponderant one.

\section{Disclosure}

The authors report no conflicts of interest in this work.

\section{References}

1. Rasmussen C. Canada's Assisted Human Reproductive Act: is it scientific censorship, or a reasoned approach to the regulation of rapidly emerging reproductive technologies? Sask Law Rev. 2004;67(1):97-135.

2. Canada. Royal Commission on New Reproductive Technologies. Proceed with care: final report of the Royal Commission of New Reproductive Technologies. Ottawa: Minister of Government Services Canada;1993. Available from: http://www.cwhn.ca/en/node/24428. Accessed November 28, 2011.

3. Reference re Assisted Human Reproduction Act, 2010 SCC 61. Available from: http://scc.lexum.org/en/2010/2010scc61/2010scc61.html. Accessed November 28, 2011.

4. Baylis F. Supreme Court of Canada decision on the Assisted Human Reproduction Act creates urgent need for action. J Obstet Gynaecol Can. 2011;33(4):317-319.

5. Constitution Act, 1867, ss. 91, 92. Available from: http://www.ownlife com/tax/ca_1867.htm. Accessed November 28, 2011. 
6. Merchant J. Assisted reproductive technology (ART) in the United States: towards a national regulatory framework? J Int Bioethique. 2009;20(4): 55-71, 109-110.

7. Jones M, Salter B. Proceeding carefully: assisted human reproduction policy in Canada. Public Underst Sci. 2010;19(4):420-434.

8. Fontanella-Khan A. India, the rent-a-womb capital of the world: The country's booming market for surrogacy. Slate Magazine. August 23, 2010. Available from: http://www.slate.com/id/2263136/. Accessed November 28, 2011.

9. Brenhouse H. India's rent-a-womb industry faces new restrictions. Time Magazine. June 5, 2010. Available from: http://www.time.com/ time/world/article/0,8599,1993665,00.html. Accessed November 28, 2011.
10. Celezic M. Everything I do revolves around my children. MSNBC News, November 11, 2009. Available from: http://today.msnbc.msn. com/id/29135612\#.TjmnO2HJTXM. Accessed November 28, 2011.

11. Wolff J. What is a father: the genetic parent. Best Life Magazine; May 16, 2007. Available from: http://www.cryobank.com/_resources/pdf/ News/Genetic-Parent.pdf. Accessed November 28, 2011.

12. Maron BJ, Lesser JR, Schiller NB, et al. Implications of hypertrophic cardiomyopathy transmitted by sperm donation. JAMA. 2009; 302(15):1681-1684.

13. Deonandan R. The Public Health Implications of Assisted Reproduction. Chronic Diseases in Canada. 2010;30(4):119-124.

\section{Publish your work in this journal}

The International Journal of Women's Health is an international, peerreviewed open-access journal publishing original research, reports, reviews and commentaries on all aspects of women's healthcare including gynecology, obstetrics, and breast cancer. Subject areas include: Chronic conditions (migraine headaches, arthritis, osteoporosis);
Endocrine and autoimmune syndromes; Sexual and reproductive health; Psychological and psychosocial conditions. The manuscript management system is completely online and includes a very quick and fair peer-review system. Visit http://www.dovepress.com/ testimonials.php to read real quotes from published authors. 